Etnográfica

Revista do Centro em Rede de Investigação em

Antropologia

vol. 17 (2) | 2013

Vol. $17(2)$

\title{
Por uma biografia das coisas: a vida social da marca Havaianas e a invenção da brasilidade
}

Toward a biography of things: the social life of the Havaianas and the invention of Brazilianness

\section{Magda dos Santos Ribeiro}

\section{CpenEdition}

Journals

Edição electrónica

URL: https://journals.openedition.org/etnografica/3148

DOI: 10.4000/etnografica. 3148

ISSN: 2182-2891

Editora

Centro em Rede de Investigação em Antropologia

Edição impressa

Data de publição: 1 junho 2013

Paginação: 341-367

ISSN: 0873-6561

Refêrencia eletrónica

Magda dos Santos Ribeiro, «Por uma biografia das coisas: a vida social da marca Havaianas e a invenção da brasilidade», Etnográfica [Online], vol. 17 (2) | 2013, posto online no dia 20 junho 2013 consultado o 09 fevereiro 2022. URL: http://journals.openedition.org/etnografica/3148 ; DOI: https:// doi.org/10.4000/etnografica.3148

\section{(c) (;) (9)}

Etnográfica is licensed under a Creative Commons Attribution-NonCommercial 4.0 International License. 


\section{Por uma biografia das coisas: a vida social da marca Havaianas e a invenção da brasilidade}

\section{Magda dos Santos Ribeiro}

O antropólogo, de acordo com Roy Wagner, é aquele que usa muito a palavra cultura. O que acontece quando empresas, marcas e bens materiais passam também a reivindicá-la? O objetivo deste texto é pensar o processo de invenção da cultura brasileira por meio da marca de sandálias Havaianas. O percurso metodológico será o de descrever sua biografia social, objetivando realizar uma análise que possibilite compreender como entidades não humanas adquirem significados e, a partir de então, passam também a agir no ambiente social. A reflexão tem como base a trajetória do objeto, imagens publicitárias e o trabalho de campo realizado em empresas e agências de publicidade entre os anos de 2008 e 2010. Neste caso particular, observaremos o processo de invenção da cultura brasileira como expressão máxima dos agenciamentos exercidos pela marca Havaianas.

PALAVRAS-CHAVE: Havaianas, brasilidade, cultura brasileira, invenção, agência de objetos.

Toward a biography of things: the social life of the Havaianas and the invention of Brazilianness - According to Roy Wagner, the anthropologist is the one that uses often the word culture. What happens when corporations, brands and material goods start to claim it as well? This article aims to think about the invention of Brazilian culture through the brand Havaianas. The methodological approach begins with the description of its social history, in order to perform an analysis which allows for a better understanding of how non-human entities acquire social meanings, and, from then on, their act in the social world. The reflection is based on the history of Havaianas, advertising images and fieldwork done in corporate environments between 2008 and 2010. Through this specific approach, the process of invention of Brazilian culture was observed as the highest expression of agency exercised by the Havaianas brand.

KEYWORDS: Havaianas, Brazilianness, Brazilian culture, invention, agency of objects.

RIBEIRO, Magda dos Santos (magdaribeiro@usp.br) - Programa de Pós-Graduação em Antropologia da Faculdade de Filosofia, Letras e Ciências Humanas da Universidade de São Paulo (PPGAS/USP), Brasil. 


\section{NÃO É NOVIDADE PARA A ANTROPOLOGIA QUE DIFERENTES GRUPOS} mobilizem categorias identitárias a fim de reforçar seus vínculos de pertencimento cultural ou assegurar seus direitos. ${ }^{1} \mathrm{O}$ que acontece, entretanto, quando são objetos materiais aqueles a reivindicar o pertencimento a dada cultura?

O objetivo deste artigo é pensar o processo de invenção da cultura brasileira por meio da marca de sandálias Havaianas. O percurso metodológico será o de descrever sua trajetória social, ${ }^{2}$ objetivando realizar uma análise que possibilite compreender como entidades não humanas adquirem significados e tornam-se, a partir de então, agentes nos espaços onde circulam.

Dois pressupostos teóricos principais darão suporte à reflexão aqui pretendida. A noção de invenção cultural, tal como formulada por Roy Wagner em A Invenção da Cultura (2010 [1975]), ${ }^{3}$ auxiliará na compreensão da trajetória deste objeto, em particular no modo como ele articulou elementos novos e convencionais da cultura brasileira e produziu, assim, seu próprio mecanismo de invenção. A noção de agência, por sua vez, permite inferir que entidades não humanas - bens materiais, objetos, imagens, animais, espíritos - sejam capazes de agir socialmente, em contraste com a ideia de que são meras mediadoras, tal como apresentado em Art and Agency por Alfred Gell (1998).

$\mathrm{O}$ artigo, portanto, se dedicará à exposição e análise da biografia da marca de sandálias Havaianas, colocando ênfase na mudança substancial que transformou um calçado popular em um objeto portador e atribuidor da "brasilidade". Tal tarefa deixará ver como as estratégias de comunicação na história deste objeto possibilitaram sua participação ativa no processo de invenção da cultura brasileira.

Ao descrever tal história, abordarei mais detidamente alguns aspectos fundamentais que permitirão compreender as principais transformações desta marca de calçados, entre eles a criação da marca Havaianas; as inscrições, cores

I O presente artigo é parte da investigação de mestrado, apoiada pela Fapesp e defendida pela autora em janeiro de 201 l, realizada entre os anos de 2008 e 2010 no Programa de Pós-Graduação em Antropologia da Universidade de São Paulo, Brasil (Ribeiro 2011).

2 A expressão "trajetória social" é usada tal como formulada por Appadurai (1986). O argumento central do autor considera que as coisas, assim como as pessoas, são possuidoras de uma vida social (1986: 15). Análoga a esta ideia é a formulação de Kopytoff (1986), cujo objetivo é compreender o mundo material através de uma abordagem biográfica das coisas. Ambas formulações serão melhor detalhadas no desenvolvimento do artigo.

3 Cabe retomar a ideia de invenção proposta por Wagner (2010 [1975]: 19). O uso do termo, segundo o autor, é mais tradicional do que parece e difere consistentemente da ideia de simulacro. Assim, a invenção não é uma espécie de simbolismo, tampouco um "buraco negro" onde a invenção devoraria a convenção; a ideia de invenção, ao contrário do que pode parece à primeira vista, está muito relacionada com a ideia de realidade (2010 [1975]: 23). Assim, sugerir que algo é fruto de uma invenção não desqualifica, jamais, seu estatuto de realidade. Invenções não são, portanto, falsificações, mas usar o termo invenção implica em esclarecer o caráter constitutivo de certas ideias e modos de pensar. Para Wagner, esses modos dizem respeito ao outro, a nós mesmos e, no limite, à constituição da antropologia. 
e desenhos que compõem sua forma; a internacionalização do produto e da marca; o estabelecimento de conexões com personalidades/artistas; o fortalecimento de laços com outros bens; por fim, a estratégia de pertencimento à cultura brasileira.

Tais aspectos destacam-se por permitirem visualizar mais claramente o curso das principais mudanças desta marca de calçados. Cabe enfatizar que tais transformações não aconteceram de maneira cronológica, ao contrário, diferentes estratégias surgem, desaparecem e ressurgem ao longo do percurso observado, o qual compreende mais de 40 anos de circulação desta marca - da década de 1960 aos anos 2000.

A trajetória de vida da marca Havaianas configurou-se como objeto de análise durante a pesquisa de campo realizada, entre os anos de 2008 e 2010, em ambientes empresariais: agências de publicidade e propaganda, institutos de pesquisa de mercado, a empresa detentora da marca - a São Paulo Alpargatas SA, além de entrevistas com designers independentes ou profissionais liberais que participaram da criação/transformação da marca, tanto no Brasil quanto em outros países. Outro recurso fundamental para sua reconstituição biográfica foi o vasto acervo de imagens publicitárias disponibilizado pelo Museu da Propaganda. ${ }^{4}$ Estas imagens formam um conjunto de mais de 240 comerciais produzidos para televisão e aproximadamente 400 anúncios produzidos para revistas nacionais e estrangeiras. Assim, é a partir da combinação desses dados - trabalho de campo e análise de documentos - que descrevo e analiso a "vida social" da marca Havaianas.

Descrever a vida social de um objeto, fazendo das imagens publicitárias um recurso fundamental - porém, não o único -, apresenta-se como alternativa à análise clássica de campanhas publicitárias. Este artigo se concentra na vida social e nos agenciamentos produzidos pela marca Havaianas, na busca por evidenciar os rendimentos de uma análise holista, em detrimento daquela que objetiva a decodificação e o desmembramento de camadas de sentido em campanhas publicitárias particulares. Logo, as imagens aqui apresentadas servem menos como suporte analítico de uma ou outra campanha e mais como um recurso metodológico para exposição empírica da trajetória de vida dos chinelos de borracha. Contudo, uma vez que as imagens aparecem enquanto um dos elementos centrais da análise aqui empreendida, explicitarei, na secção seguinte, os rendimentos deste método, cuja utilização de imagens publicitárias aparece como um importante recurso de reconstituição histórica e biográfica do objeto analisado.

4 O Museu da Propaganda fica localizado na cidade de Porto Alegre, Brasil, e me permitiu o acesso a parte do acervo sobre a marca Havaianas e sua reprodução. 


\section{POR UMA BIOGRAFIA DAS COISAS}

Na década de 1970, acontece uma profusão de estudos sociológicos e antropológicos sobre as sociedades consumidoras de bens. O que esses trabalhos buscavam discutir, a partir de exemplos concretos e evidências empíricas, era, principalmente, o significado social dos bens materiais. ${ }^{5}$

Bastante influenciado pela teoria saussuriana, Roland Barthes (1967) desenvolve uma análise estruturalista do vestuário feminino a partir da apreciação dos discursos visual e verbal. Cabe destacar que Barthes foi precursor na análise sistemática de imagens publicitárias, determinado a compreendê-las como plenas de sentido e muito propícias para o desenvolvimento de uma análise semiológica. ${ }^{6} \mathrm{Tal}$ método de análise influenciou fortemente trabalhos vindouros, interessados em compreender os discursos presentes nas imagens publicitárias e também em realizar uma crítica ao crescimento da publicidade e, consequentemente, do consumo.

Sabemos, contudo, que o discurso publicitário não é uma prática atemporal. Como todo gênero discursivo, a publicidade possui uma história e se inscreve nas mutações de um corpus econômico e social. Para Adam e Bonhomme (2005), dois grandes fenômenos caracterizaram a complexidade argumentativa do discurso publicitário: o primeiro é a estrutura escrita e dissertativa do texto enquanto imagem; o segundo é a essência visual do discurso publicitário, onde a imagem, desta vez, transforma-se em texto. Assim, é a partir dessa ambiguidade e da relação híbrida entre texto e imagem, inerente à publicidade, que os autores analisam sua capacidade persuasiva e retórica.

Minot (2001), por outro lado, pensa a publicidade como um recurso poderoso de propagação de certas ideias. $\mathrm{O}$ autor a compreende como um dos principais elementos de um sistema de comunicação mais amplo, o qual abarca ideias que fazem parte de um inconsciente coletivamente compartilhado. É através da publicidade que essas ideias são divulgadas de maneira repetitiva, aumentando, assim, sua capacidade de memorização e fixação social.

Ainda que a publicidade tenha sido estudada tradicionalmente pelas "teorias da comunicação", ela configurou-se como objeto de análise em diversos e distintos trabalhos. Algumas contribuições centraram-se em sua dimensão

5 Dentre estes estudos, destacaram-se aqueles que propuseram realizar uma severa crítica à cultura de massa e ao aumento desenfreado do consumo e da publicidade nas sociedades industriais e capitalistas. A exemplo de importantes contribuições como as de Baudrillard (1968, 1970), Bourdieu (2006 [1979]), Barthes (1957, 1967, 1970), Douglas e Isherwood (2006 [1979]), Sahlins (2003 [1976]), entre outros, vimos proliferar as reflexões sobre o mundo dos objetos. Cabe mencionar a forte influência marxista e estruturalista, em voga na época, presente neste conjunto de obras.

6 Um dos principais artigos que marca seu interesse pela publicidade é "Rhétorique de l'image" (1964, Communications, 4: 40-51), onde Barthes analisou, sistematicamente, a partir de uma perspectiva semiológica, o anúncio de massas Panzani. O artigo também está disponível em língua portuguesa em Barthes (1990). 
sociológica (Baudrillard 2000 [1982]; Cathelat 2001; Debord 2000), outras na vertente psicológica (Packard 1958; Haineault e Roy 1984; Khel 1998), ou linguística (Charaudeau 1994; Greven 1982; Grunig 1998; Pereira 2006), além dos consagrados estudos de semiologia (Joly 1994; Floch 2002).

Muitos destes trabalhos tiveram como inspiração a perspectiva analítica de Barthes (1957, 1967, 1970, 1990), para quem a publicidade pode ser pensada como um mito. O mito, por sua vez, é entendido como um sistema de comunicação, uma mensagem, um conceito, uma ideia e, sobretudo, um modo de significação. Barthes (1970: 211 ) vislumbrou na ciência semiológica um método analítico que pudesse dar conta do rápido e crescente aumento da publicidade e de outras técnicas a serviço da mercantilização.

Todas essas vertentes de pesquisa acerca da constituição da publicidade - semiótica, sociológica, retórica, psicológica, linguística, discursiva - contribuíram imensamente para estabelecer um corpus de análise consistente sobre os efeitos dessa prática nas sociedades contemporâneas. Entretanto, muitos destes trabalhos, como afirmou Minot (2001: 10), revelam ao final uma fórmula bastante conhecida e desgastada: "a finalidade da publicidade é vender!" Se satisfazer com tal formulação, entretanto, é ocultar a complexidade e a variedade dos modos de reconhecimento das mensagens publicitárias e, sobretudo, as respostas sociais que recebem.

Ainda que as análises clássicas de campanhas publicitárias revelem a astúcia da técnica por trás da cortina do espetáculo capitalista, elas pouco têm a dizer sobre a prática empresarial de produção da publicidade. Dito de outra maneira, é como se essas análises revelassem o truque do mágico, deixando-o desconcertado no palco, sem levar em conta todo o trabalho e treinamento investido em sua exibição. Mais do que isso, é como se o espetáculo contasse apenas com a persuasão do mágico e a ingenuidade de seu público, deixando de fora todos os artefatos - varinhas, pombos, coelhos e cartolas - indispensáveis para a atividade ilusionista. Neste sentido, quero reforçar o fato de que nas análises clássicas de campanhas publicitárias o foco da discussão centra-se na técnica persuasiva (seja esta retórica, discursiva, psicológica, semiológica, etc.) e jamais nos objetos que se beneficiam de tal técnica. Uma abordagem preocupada com a circulação de objetos nas sociedades contemporâneas não poderá restringir-se a estes estudos, uma vez que o objeto em si - bem como sua trajetória em um contexto social particular - oferece o cerne de uma abordagem biográfica das coisas.

A antropologia, por sua vez, tem provido contribuições interessantes para o estudo da publicidade. No volume Advertising Cultures (Malefyt e Moeran 2003), ${ }^{7}$ diversos autores discutem o papel da publicidade e seus mecanismos

7 O volume foi produzido a partir do primeiro grupo de trabalho organizado em torno do papel da publicidade nas sociedades contemporâneas, no encontro da American Anthropology Association (AAA) no ano de 2000, intitulado "In-and-of andvertising: the role for anthropology". 
de produção em diferentes culturas. Miller (2003), por exemplo, analisa campanhas publicitárias particulares durante sua pesquisa de campo em Trinidad a fim de compreender mais claramente a circulação de certas ideias naquele contexto social. $\mathrm{O}$ interessante destes trabalhos é justamente a análise da prática publicitária em diferentes contextos culturais, diferentemente das abordagens semiológicas descritas anteriormente, as quais tendem a desconectar a técnica de persuasão publicitária de seu contexto de produção, reduzindo todas as culturas à "cultura capitalista".

Além disso, a ênfase analítica dos estudos semiológicos repousa, eminentemente, sob a ação humana. Essa ideia fica clara no clássico exemplo do buquê de rosas fornecido por Barthes (1970: 219): "Um buquê de rosas é capaz de fazer significar a paixão”. Há, portanto, um significante (rosas) e um significado (paixão); contudo, no plano da análise semiológica há mais um termo, já que as rosas carregadas de paixão podem ser decompostas em rosas, de um lado, e em paixão, de outro, ou seja, uma e outra já existiam antes de se unirem e formarem este terceiro objeto, o qual Barthes denomina signo.

Ora, se estamos de acordo que a rosa é representativa do sentimento de paixão, surge, por conseguinte, uma questão fundamental: quais fenômenos culturais fizeram com que a rosa pudesse conter, ela mesma, a paixão? Em outros termos, como entender os processos a partir dos quais o significante e o significado produzem o signo?

Tal exemplo coloca em relevo um dos elementos centrais desse tipo de análise. O foco da observação e da descrição recai sob a ação humana. É precisamente o homem que faz significar sua paixão através das rosas e não as rosas, elas próprias, que são capazes de transmitir a paixão.

Outro tipo de abordagem bastante frequente, no âmbito dos estudos sobre os bens materiais, é aquela que relaciona, diretamente, o consumo com a produção de identidades sociais. Nesses trabalhos impera a ideia de que a escolha de determinados objetos ou marcas é dada como meio de definir-se socialmente. Campbell (2006: 48) discute o consumismo moderno como aquele ligado à afirmação, confirmação e até mesmo construção da identidade; assim, o autor aceita que "o consumismo é fundamental para o processo pelo qual os indivíduos confirmam ou até criam sua identidade" (Campbell 2006: 51). Novamente, a ênfase encontra-se na ação humana, no fato de o indivíduo escolher, dentre uma infinidade de objetos, aqueles mais bem capazes de representar sua identidade social.

Assim também são as análises bourdianas acerca dos bens materiais. Para Bourdieu "a cosmética corporal, o vestuário ou a decoração da casa - constituem outras tantas oportunidades de experimentar ou afirmar a posição ocupada no espaço social” (Bourdieu 2007 [1979]: 57). Tais análises acerca da constituição social do "gosto" e da "classe" são interessantes na medida em que pormenorizam a agência humana frente aos espaços demarcados por objetos; 
contudo, o olhar repousa sob os agentes humanos e sob a cultura, também entendida enquanto um lócus de interferência e transformação fundamentalmente humana.

Indagamos, pois, quais são os processos sociais capazes de fazer com que bens materiais, coisas, objetos ou marcas possuam identidade. Se os bens não nascem contendo seus sentidos, então, quais são os fenômenos sociais que fazem significar os bens, para que eles, a posteriori, possam significar os homens?

Sugerir que os objetos, bens materiais e marcas sejam possuidores de uma vida social, tal como fez Appadurai (1986), nos ajuda a entender que as coisas, assim como as pessoas, possam ser pensadas a partir de uma história biográfica. O olhar desloca-se, portanto, para as coisas trocadas e não apenas para as formas, funções ou consequências destas trocas, evidenciando as condições sob as quais objetos podem circular em diferentes regimes de valor no tempo e no espaço. Essa perspectiva, todavia, difere, em larga medida, daquela descrita anteriormente, onde os objetos indicam as posições sociais dos atores. Aqui, diferentemente, são a circulação e as transformações dos objetos materiais, ao longo de um período temporal representativo, que interessam.

Appadurai (1986: 17) apresentou objeções à forte tendência teórica que considerava o mundo das coisas inerte e mudo, sendo movido, animado e reconhecível apenas por intermédio das pessoas e de suas palavras. De acordo com o autor, "temos que seguir as coisas em si mesmas, pois seus significados estão inscritos em suas formas, seus usos, suas trajetórias. Somente pela análise destas trajetórias podemos interpretar as transações e cálculos humanos que dão vida às coisas" (Appadurai 1986: 17). Em outras palavras, se eram os objetos materiais que conferiam identidade, posições ou significado aos homens, agora veremos como os homens conferem autonomia aos objetos, para que eles possam não somente representar, mas, fazer.

Assim, de certo ponto de vista teórico, atores humanos podem codificar as coisas por meio de suas significações; entretanto, a partir da perspectiva aqui proposta, são as coisas em movimento que elucidam os sentidos da sociabilidade humana. Poderemos, então, compreender os objetos materiais enquanto, simultaneamente, receptores e produtores de valores, pressupondo que pessoas e coisas são igualmente significativas no curso de suas interações. As imagens publicitárias servirão, nesta perspectiva, como importantes elementos de reconstituição histórica e social do objeto analisado, fornecendo o percurso visual a partir do qual poderemos compreender a ação particular dos chinelos de borracha.

Veremos, na análise da trajetória deste objeto, duas estratégias recorrentes. A primeira visa colocar as Havaianas ao lado dos demais calçados, isto é, a marca pretende ser entendida como um calçado "elegante" e não como a alternativa daqueles que não têm condições de comprar um calçado melhor. A segunda - a qual consegue, ao longo dos anos, se hibridizar à primeira - 
é aquela que aproxima as sandálias Havaianas da cultura brasileira, para então fazer com que ela própria contenha e transmita a brasilidade.

\section{A VIDA DE HAVAIANAS}

Em 1907, a São Paulo Alpargatas SA instala-se no bairro da Mooca, em São Paulo. Dedica-se, inicialmente, à produção de lonas e encerados e em poucos anos é uma das principais produtoras de calçados "alpargatas", um dos mais baratos disponíveis no Brasil.

Inspirada pelas sandálias japonesas Tatami Zôri, caracterizadas pelo solado simples feito com palha de arroz e tiras de tecidos, a empresa lança, em 1962, o primeiro modelo de sandálias de borracha com o nome Havaianas. A partir de então, um grande esforço é empreendido para divulgar e comercializar esse objeto no país.

Uma das primeiras campanhas publicitárias produzidas para divulgação da marca, ainda na década de 1960, foi um filme comercial para televisão, cuja preocupação estava em apresentar e indicar os benefícios do produto, recomendando-o para toda a família.

As cenas dessas campanhas (figura 1) apresentavam um modelo normativo de família, onde todos - em casa, na praia ou no clube - usavam sandálias Havaianas. As comunicações desta época esforçavam-se por apresentar o produto e também por caracterizá-lo como sendo "de classe", ou seja, desde sua concepção, Havaianas jamais comunicou seu calçado como popular. Assim, muito embora a marca tenha divulgado desde o início seu calçado como "sofisticado”, não era assim que o público o compreendia. É apenas cerca de 30 anos depois da divulgação destas imagens - e de milhões gastos em publicidade que os chinelos conseguem modificar, enfim, sua aceitação no mercado.

Em outro filme comercial (figura 2), as sandálias Havaianas conversam: "Você também é Havaianas, não é?", pergunta a sandália. "Mas como é que você sabe?", indaga a outra. "Ora, pela classe!" Nessas primeiras imagens publicitárias, já encontramos algumas daquelas que seriam as estratégias principais da marca: oferecer sandálias para gêneros e idades diferentes; sugerir seu uso em momentos de descanso e lazer; apresentar o produto como "elegante" e utilizado por pessoas de "classe". ${ }^{8}$

Muito embora se tenha nutrido uma ideia de que houve uma transformação brusca no modo como esse bem material foi entendido e recebido no Brasil - durante muito tempo calçado popular e, repentinamente, de moda -,

8 Os termos e adjetivos usados para divulgação da marca se modificam de acordo com as diferentes épocas vivenciadas pelo objeto, porém enfatizo aqui a adjetivação recorrentemente elitista ou ligada aos aspectos da moda. Em diferentes momentos as frases apelaram para termos como: elegante, de classe, fashion, na moda, legítima,verdadeira, entre outros. 

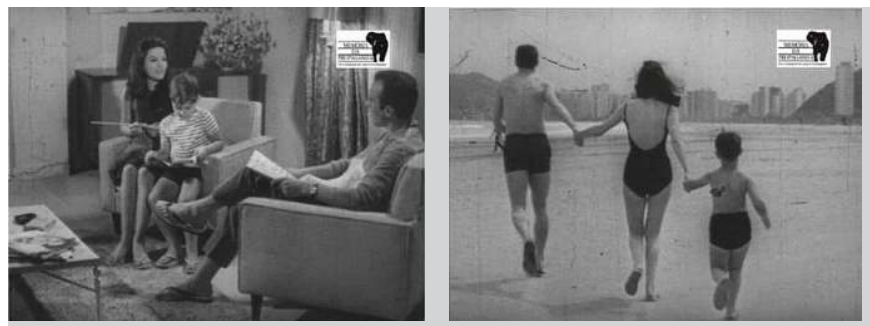

Figura 1

Família de Havaianas

(1963).
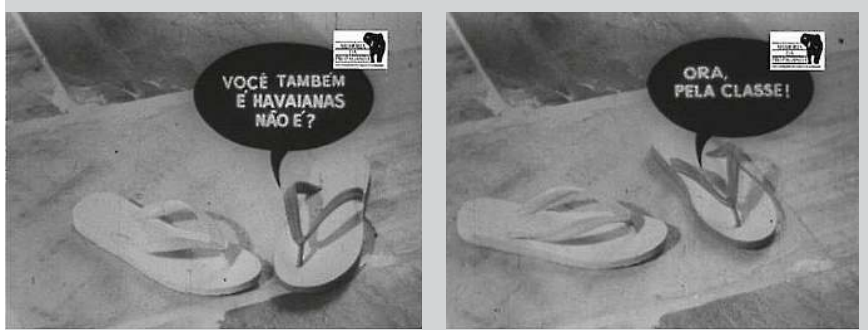

Figura 2

Havaianas conversam (1965).
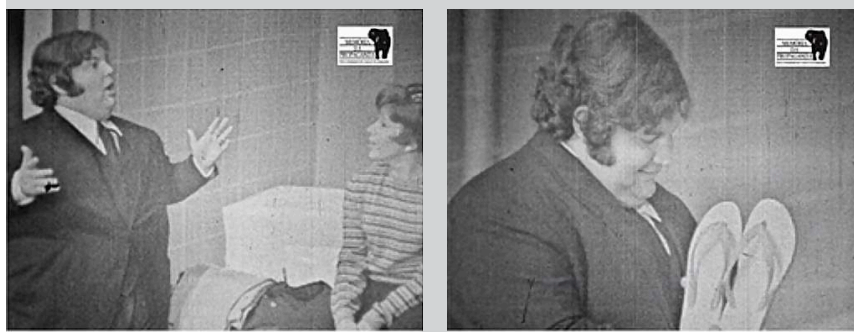

Figura 3

Família Trapo (1968).

Fonte das imagens:

Comerciais televisivos obtidos junto ao Museu de Propaganda, Porto Alegre, Brasil.

observamos nas imagens e documentos evidências de que os esforços foram contínuos e insistentes para que as sandálias não fossem entendidas, jamais, como a alternativa daqueles que não poderiam comprar um calçado mais caro.

Outra ideia que se tornará substancial para compreendermos as transformações da marca é aquela que, primeiramente, sugere e, posteriormente, efetiva a internacionalização do produto. Muito embora as sandálias Havaianas tivessem sido vendidas para outros países somente no final dos anos 90, no ano de 1968 já encontramos sugestões de que as Havaianas seriam enviadas para "amigos no exterior". O diálogo aparece em um programa popular exibido pela rede Record de televisão (figura 3).

A Família Trapo, programa do gênero comédia, tinha como protagonistas Ronald Golias, Otello Zeloni e Jô Soares - figuras emblemáticas do humor brasileiro -, os quais anunciavam as sandálias durante a exibição das cenas. Destaco uma dessas aparições, cena em que o mordomo Gordon (G), interpretado por Jô Soares, conversa com a personagem Verinha Trapo (V), interpretada por Cidinha Campos:

“v Gordon você sabe que você até que é um cara elegante! 
G Obrigada, mas isso faz parte da profissão, a senhora sabe que um bom mordomo tem que ser elegante, tem que ter aparência, enfim, tem que ter status.

V Tem que ter o quê, Gordon?

G Status! Quando ele entra tem que desfilar com garbo, com majestade, ele passa, entra e diz: "O almoço está servido" e as pessoas têm que fazer ohhh!

V Ohhh, e onde é que você compra roupa, Gordon, encontrar aqui para o seu tamanho não é bolinho não!

G Mas a minha roupa é toda importada, eu tenho um amigo meu, o Ciro, que trabalha para uma família que viaja muito, então cada vez que ele vai aos Estados Unidos ele traz roupas para mim, pois lá tem casas especializadas em roupas para pessoas privilegiadas como eu.

V Bacana, e essa sandália aqui você também traz dos Estados Unidos?

G Não, essas sandálias aqui eu envio para meus amigos do exterior, são as legítimas sandálias Havaianas."

A ideia de que um objeto brasileiro possa ser enviado "ao exterior", em particular no início da década de 1970, é emblemática na medida em que mostra os primeiros esforços de divulgação da marca no Brasil a partir da possibilidade de sua aceitação internacional. Apesar das diferentes campanhas publicitárias da época e de sua inserção pioneira em programas humorísticos brasileiros, os atributos relacionados à "sofisticação" das sandálias Havaianas não eram tão eficientes para a venda do calçado como a empresa esperava. Segundo um dos profissionais de marketing que trabalhou para a marca, "as pessoas não queriam sair de casa de chinelos, elas temiam serem confundidas com pessoas muito pobres, que não tinham condições de comprar um calçado melhor [...]. Nosso desafio era tirar a vergonha de usar Havaianas em público" [notas do caderno de campo, entrevista com os profissionais de marketing da São Paulo Alpargatas, outubro de 2009].

A empresa passa a buscar alternativas para melhorar a imagem dos chinelos no mercado e contrata um dos maiores comediantes brasileiros em voga na época, firmando, com o ator Chico Anysio, uma parceria de muitos anos (figura 4). O ator passa a protagonizar cenas com suas diferentes personagens na divulgação das sandálias Havaianas. Contudo, a ênfase nas características funcionais do objeto continuava a caracterizar as campanhas por meio do conhecido slogan "As legítimas Havaianas não deformam, não soltam as tiras e não tem cheiro".

Nas dezenas de filmes comerciais onde Chico Anysio representa suas personagens elogiando as Havaianas, ele reforça as principais características das sandálias de borracha. Interessante notar os variados espaços cenográficos onde os comerciais são filmados. Na praia, os amigos bebem uma cerveja e 



Figura 4

Chico Anysio e Havaianas

(1971).
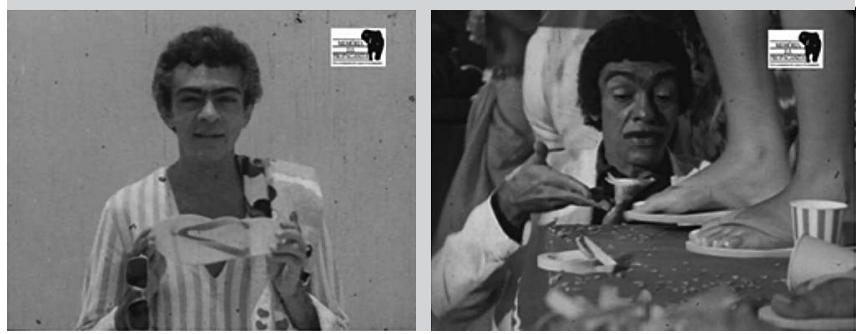

Fonte: Comercial televisivo

obtido junto ao Museu de Propaganda, Porto Alegre, Brasil.

afirmam que as Havaianas combinam, perfeitamente, com o clima tropical do Brasil. Em outra imagem, Chico Anysio mostra os pés que sambam no carnaval brasileiro calçando Havaianas. Além destas, são exibidas inúmeras cenas em ambientes de compras, supermercados e lojas de calçado.

Apesar de todos esses esforços, até o início dos anos 90, o principal público das sandálias ainda eram as camadas populares. ${ }^{9}$ Assim, na década de 1990, a empresa decide passar a responsabilidade pela criação de suas campanhas para uma das maiores agências de publicidade da cidade de São Paulo. ${ }^{10}$ A partir de então, as estratégias empresariais para a venda de Havaianas se voltam fortemente para a associação do produto a outras pessoas e outros bens. Como vimos, a marca vinha buscando arduamente ser entendida como um produto passível de uso pelas "elites", embora, de fato, seu uso fosse prática dos trabalhadores mais humildes - empregadas domésticas, pedreiros, faxineiros, etc.

A marca passa, então, a criar campanhas publicitárias onde seu uso acontece na casa de atores, atrizes, cantores, cantoras, atletas e pessoas influentes na mídia brasileira. Essa diversificação foi fundamental para a mudança na maneira como a marca era percebida e entendida, pois, além da imagem do

9 Dados obtidos segundo entrevistas fornecidas pelos publicitários e profissionais de marketing que trabalham para a marca. Segundo Rui Porto, diretor de comunicação de Havaianas, em entrevista concedida em Março de 2009: "Estávamos buscando a classe média. Além de mudarmos um pouco o produto, demos conforto emocional ao consumidor que adorava usá-las em casa, mas não tinha coragem de sair com as sandálias na rua."

10 A Almap/BBDO passou a ser a responsável pelas campanhas publicitárias da marca Havaianas. Seu diretor de criação, Marcelo Serpa, propõe uma estratégia ousada, muito discutida pela empresa em razão do alto valor que seria investido na contratação de "personalidades famosas". 
ator Chico Anysio, já desgastada e utilizada por muitos anos, a marca passou a manter relacionamento com outras figuras emblemáticas, mudando, assim, os sentidos relacionados ao seu produto e à sua imagem. Desta vez, a ambientação passa a ser casa de cantores, artistas e "famosos" da televisão brasileira, na grande maioria mansões luxuosas ou casas de veraneio (figura 5).

\section{Figura 5}

Famosos de Havaianas (1995): atriz Vera Fischer; atriz Letícia Spiller; jogadora de basquete Hortência Marcari; e socialite Thereza Collor de Mello.

Fonte: Comercial televisivo obtido junto ao Museu de Propaganda, Porto Alegre, Brasil.
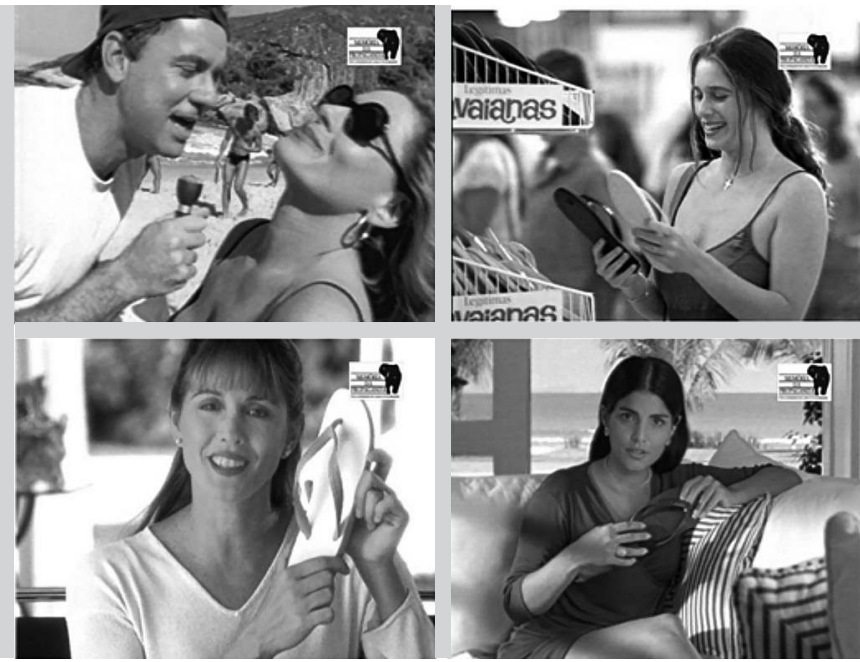

As imagens publicitárias são entendidas, aqui, enquanto fragmentos ou partes da marca Havaianas, isto é, o objeto da comunicação - a partir dos anos 90 - deixa de ser centrado nas características físicas do produto e passa a focar elementos abstratos relativos à marca. Esses elementos, contudo, são capazes de estabelecer um primeiro vínculo na relação do objeto com as pessoas. Na medida em que a marca é capaz de evidenciar como seu produto adquire diferentes sentidos frente às condições estéticas e tecnológicas presentes em suas imagens, as Havaianas passam a compartilhar de nossa vida social em razão do tráfego intenso que possuem em inúmeras cenas do cotidiano. Cabe enfatizar, neste caso, que as imagens, mais do que produzir informações sobre o produto, contêm, elas mesmas, fragmentos do objeto.

Conforme sugeriu Gell (1998), o objetivo da análise não é decodificar ou entender essas imagens enquanto textos a serem lidos, mas compreender a relação que estas estabelecem com as pessoas enquanto objetos dotados de intenção. As imagens publicitárias possuem a capacidade de narrar e de intervir na historicidade destes objetos, de modo que as características funcionais dos bens, por mais enfatizadas que sejam, só poderão ser comprovadas no uso sensível dos produtos - por exemplo, sentir a maciez, o conforto ou, ainda, a ausência de cheiro. Entretanto, quando as imagens tratam de outras características sensíveis como sentimento de pertencimento, status, estilo, alegria, vivacidade, etc., a eficácia já se dá na relação com as imagens. 
As diferentes tentativas da marca de alternar e incluir outros locais de uso para os chinelos exemplificam bem o potencial das imagens publicitárias para criar novas práticas de usos e sentidos aos objetos. As Havaianas passam a partilhar o espaço do guarda-roupa, do closet, e não mais o espaço da lavanderia, do quintal. A ampliação dos repertórios de uso expressados pela marca através da produção de um vasto conjunto de campanhas publicitárias corrobora mudanças em seu uso cotidiano, colocando o objeto em diferentes tipos de relações, seja com outros objetos - roupas, acessórios, carros -, seja em diferentes lugares - festas, restaurantes, mansões, etc.

Observar a trajetória social deste bem permite conhecer os efeitos de sua existência e observar seus modos de criatividade. Olhar para sua história coloca em evidência as fronteiras temporais desse processo e permite acompanhar a relevância temática que envolve o incômodo da marca em estar associada às camadas populares, buscando aproximar-se das elites brasileiras. Assim, após dedicar grande investimento para associar seu produto às "elites", a marca Havaianas volta, mais determinada, a associá-lo ao Brasil. Logo, percebemos que ao longo de sua trajetória houve inúmeras tentativas de conformação deste bem material que, em diferentes épocas e contextos sociais, apelou para esta ou aquela estratégia, colocando em relevo as convenções culturais, estéticas e tecnológicas dos diferentes contextos vividos pela marca.

Durante seu percurso de existência, cabe abordar também aquelas mudanças que tiveram implicações físicas no objeto. No início dos anos 2000 a tecnologia de impressão fez com que a marca Havaianas criasse uma gama de desenhos e inscrições nos solados das sandálias. Assim, a imagem de seu produto passa a ser composta por diversos padrões decorativos, os quais são capazes de amplificar sua compreensão enquanto "artigo de moda", já que tais padrões permitem combinações e associações com outros bens materiais. Tal estratégia sofisticou a aparência visual das sandálias, reforçando a existência de uma estética própria à marca (figura 6).

O estilo, para Gell (1998: 159), deve ser entendido de modo muito mais cognitivo do que taxonômico. Neste caso, as diferenças estéticas podem ser entendidas como diferenças de cognição, as quais estabelecem vínculos a partir de suas características peculiares e de sua "personalidade". O recurso proposto por Gell (1998: 159) é o de associar o estilo ao significado, isto é, determinados padrões visuais associam-se de modo íntimo com determinadas

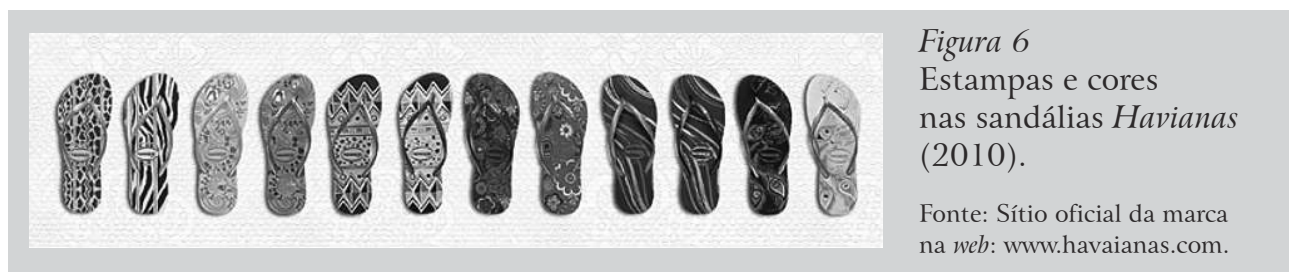


culturas, de modo que tal "estética cultural" permita a identificação de padrões e formas particulares. Dito de outra maneira, quando Gell (1998: 159) analisa os artefatos das Ilhas Marquesas ele percebe um padrão cognitivo particular e verifica como esse padrão associa-se intimamente com a cultura analisada. Nessa direção, podemos inferir que as marcas, no universo dos bens materiais, não se restringem a seus símbolos (logotipos) como instrumento de identificação. Elas contam também com padrões estilísticos particulares - formas, cores, desenhos, estampas - para tornarem-se reconhecíveis, não apenas de forma taxonômica (classificada hierarquicamente no universo de bens), mas cognitiva - despertando sensações e produzindo vínculos afetivos.

Para a marca Havaianas, a possibilidade de anexar padrões decorativos ao seu chinelo de borracha altera a relação entre as pessoas e o objeto. Em outras palavras, acontece um fenômeno bastante interessante relacionado à forma, estilo e atributos dos chinelos de borracha - como uma categoria de bens -, ocasionado pela existência e pela trajetória de vida de Havaianas. Isto é, apesar de óbvio o fato de que os bens materiais considerados "líderes de mercado" sejam "copiados" por outros bens do mesmo tipo, acontece um fenômeno interessante no fato de as demais marcas de sandálias seguirem o estilo Havaianas, tanto nos discursos publicitários, quanto na forma estética.

Do ponto de vista antropológico, essa é mais uma forma de ação dos bens materiais, ou seja, quando bem-sucedidos socialmente - e, sobretudo, comercialmente -, eles incitam todo um universo de produção de bens similares. O Brasil passa, então, a ser povoado por chinelos de borracha que querem, todos eles, ser como Havaianas. É o que observamos no exemplo etnográfico descrito pela antropóloga M.S. Coelho de Souza (2012).

Souza (2012) narra os conflitos decorrentes do acordo comercial estabelecido entre a marca de sandálias Ipanema, concorrente da marca Havaianas, e a população indígena Kïsêdjê (Suya). O objetivo do acordo era firmar um contrato comercial para utilização dos padrões indígenas Kïsêdjê nas imagens publicitárias e embalagens da marca Ipanema. Muito embora o objetivo do artigo seja demonstrar os mal-entendidos derivados das diferentes perspectivas em contato - indígena e empresarial -, observamos o grande esforço da marca Ipanema em aproximar-se de certa noção de brasilidade, via padrões e desenhos de uma população indígena, divulgando-os através do corpo da modelo, também brasileira e reconhecida internacionalmente, Gisele Bündchen. Logo, observamos como os padrões estéticos e as ideias mobilizadas por determinados bens materiais são consistentes a ponto de influenciar a trajetória social de outros bens semelhantes, impactando todo um conjunto de relações entre pessoas e coisas.

A capacidade da marca Havaianas de intercambiar subjetividades - com pessoas, mas também com outros bens - apresenta-se como uma de suas características principais, uma vez que aquilo que a marca troca é, antes, objeto 
da sua constituição. Isso significa que, ao longo da trajetória de circulação da marca Havaianas - considerando a circulação de suas imagens, discursos, valores e o próprio objeto -, a marca pôde receber sentidos que agora são (re)transmitidos. Veremos na próxima secção que os sentidos relacionados à brasilidade tornaram-se cada vez mais intensos e intrínsecos à marca, naturalizando sua capacidade de ação.

\section{CHINELOS DE BORRACHA COMO CULTURA BRASILEIRA}

Durante as décadas de 1970 e 1980, além do grande número de campanhas publicitárias protagonizadas por Chico Anysio, visando anunciar as Havaianas, circularam também outras campanhas que começam a aproximar, cada vez mais explicitamente, a marca do imaginário brasileiro. Um destes comerciais apresentou como protagonista uma mulher, caracterizadamente vestida de Carmen Miranda, a cantar, em cima de uma grande sandália Havaianas - a funcionar como palco -, uma música com letra que remetia às características principais da sandália, enfatizando sua durabilidade, beleza e conforto. Em outro comercial, figuravam pessoas de diferentes países, vindas como turistas ao Brasil para apreciar as sandálias Havaianas, apresentadas no comercial como a "oitava maravilha do mundo", além de orgulho nacional (figura 7).

O chinelo de borracha Havaianas passa a ser colocado ao lado de elementos convencionalmente aceitos como representantes da brasilidade - as praias, o Carnaval, Carmen Miranda -, mas também associa-se a elementos não tão óbvios, como as festas juninas e outras festas populares (figura 8).

Nessas campanhas publicitárias, as quais buscavam retratar as festas de Carnaval, a apreciação do produto por estrangeiros, os jogadores de futebol e as festas tradicionais, aparece a possibilidade de divulgação da marca enquanto
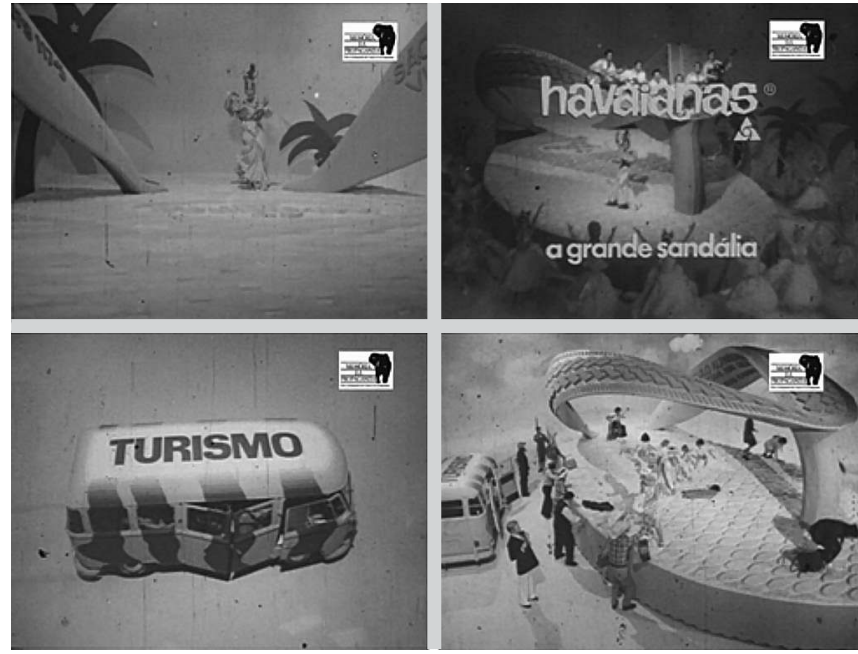

Figura 7

Carmen Miranda e turistas anunciam as sandálias Havaianas (1982).

Fonte: DVD Havaianas, edição especial obtida junto ao Museu de Propaganda, Porto Alegre, Brasil. 


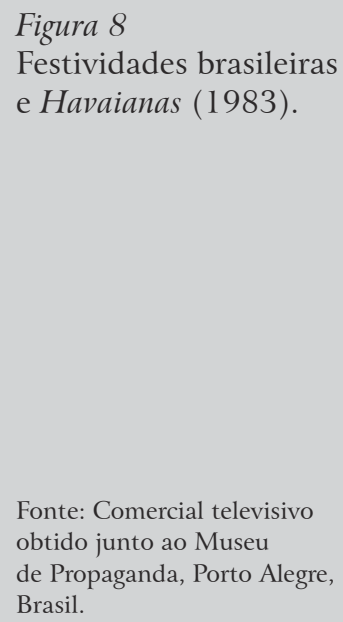

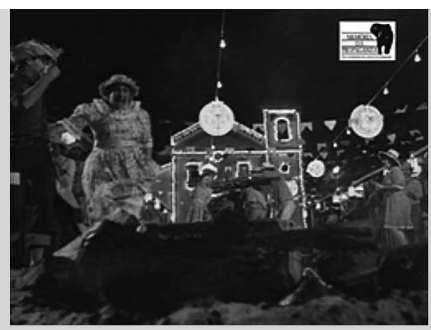
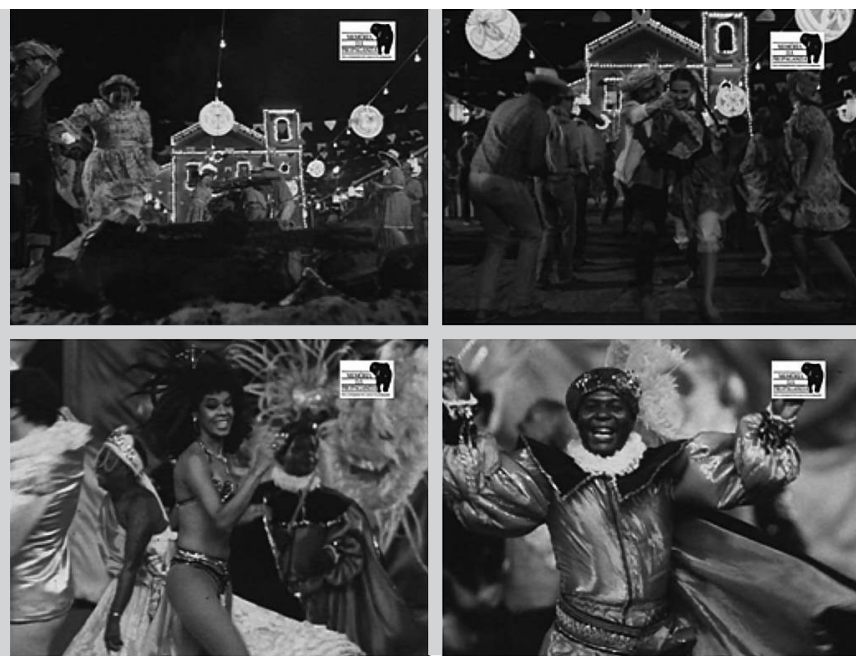

a "legítima sandália brasileira". Tal ideia, entretanto, fica encubada no imaginário da marca e volta a aparecer com força alguns anos depois.

Quando a empresa São Paulo Alpargatas decide efetivar a exportação do produto para outros países, nos anos 2000, a associação dos chinelos de borracha com a cultura de seu país de origem volta a ganhar espaço nas campanhas publicitárias. Ao decidir pela expansão de seus negócios, Havaianas dirige-se imediatamente à Europa, considerada pelos executivos da São Paulo Alpargatas um dos locais mais adequados para divulgar um calçado brasileiro e transformá-lo em artigo de "moda" e "luxo":

"A Alpargatas só decidiu levar a sério a exportação no ano 2000, começou pela Itália e França. O resultado foi que tivemos boa resposta das 'vítimas da moda'. As Havaianas chegaram às Galerias Lafayette, em Paris, e à 5. a Avenida, em Nova Iorque, entre outras lojas de artigos de luxo. A revista Vogue americana já a citou três vezes em sua prestigiada lista de "Must Have". Nina Garcia, ex-diretora da revista Elle e júri do programa de moda Project Runway, escreveu sobre as sandálias brasileiras em seu novo livro, The One Hundred, como um dos três produtos principais no meio de cem coisas que as mulheres precisam ter" [Rui Porto, diretor de comunicação e mídia da marca Havaianas, entrevista cedida ao jornal Folha de São Paulo em 28/10/2008].

"Gostaria de citar alguns fatos que contribuíram para o sucesso da Havaianas no mundo e que foram estrategicamente analisados. Consolidar a marca Havaianas em mercados que chamamos de high end ou topo da pirâmide foi uma das estratégias que adotamos para posicionar a marca e para transmitir a imagem ícone do nosso país, escolhemos países formadores de opinião no mundo da moda: França e Itália foram selecionados primeiramente por 
serem importantes centros difusores de moda" [Ângela Hirata, consultora de comércio exterior para a marca Havaianas, entrevista cedida ao jornal Estado de São Paulo em 12/4/2007].

Com efeito, nos anos 2000, a marca Havaianas passa a expandir estrategicamente sua circulação e comercialização em outros países; nessa ocasião, a ideia de associar-se a um "estilo brasileiro" parece, para a marca, perfeitamente adequada.

Leitão (2007), ao analisar o consumo de moda e vestuário brasileiros na França, encontra uma forma de consumo tido como exótico, levantando questões sobre alteridade e identidade. São examinadas, em sua pesquisa, algumas particularidades sobre o ato de "consumir o outro", explicitadas nos discursos franceses sobre os produtos brasileiros. O caso da pesquisadora é esclarecedor na medida em que se aproxima bastante do objeto aqui em questão e permite compreender diferentes estratégias de internacionalização de objetos e marcas e sua recepção em países europeus.

A questão, entretanto, é menos analisar narrativas particulares apresentadas pela marca e mais refletir sobre seu trânsito em diferentes contextos, épocas e momentos sociais. Isso significa, sobretudo, observarmos os mecanismos de autoexpressão e definição através dos quais a marca exercita suas aparições. Tal abordagem permite, portanto, evidenciar uma carreira social de sucesso, ou seja, reconhecida coletivamente como bem-sucedida. Nesse sentido, Kopytoff (1986: 66-67) sugere que para conhecer a biografia de uma coisa deveríamos fazer perguntas similares àquelas que faríamos às pessoas:

"Quais são, sociologicamente, as possibilidades biográficas inerentes a esse 'status', e à época e à cultura, e como se concretizam essas possibilidades? De onde vem a coisa e quem a fabricou? Qual foi sua carreira até aqui, e qual é a carreira que as pessoas consideram ideal para esse tipo de coisa? Quais são as 'idades' ou as fases da 'vida' reconhecidas de uma coisa, e quais são os mercados culturais pra elas? Como mudam os usos da coisa conforme ela fica mais velha, e o que lhe acontece quando sua utilidade chega ao fim?" (Kopytoff 1986: 66-67, aspas no original).

Tornam-se claras as estratégias da marca para se aproximar de um imaginário de práticas tidas como brasileiras. A princípio, como vimos, as imagens incluíam as sandálias nas cenas e nas atividades, isto é, samba-se no Carnaval de Havaianas, anda-se na praia calçando Havaianas, pula-se a fogueira de São João de Havaianas. Veremos, na sequência, que a marca Havaianas passa a incorporar, ela própria, a identidade de pessoa brasileira.

A marca Havaianas lança, no ano de 1998, na ocasião da copa do mundo de futebol, um modelo de sandálias que leva nas tiras a bandeira do Brasil. 
Tal estratégia foi fundamental para que o objeto portasse, além da marca do produto, uma identificação explícita de seu país de origem. A ideia de que "trazemos o Brasil no peito, peito do pé, mas peito" (figura 9) reforça o discurso pessoalizado dos chinelos de borracha, apresentando-se como um objeto que possui preferências e torce por seu país.

Com a estratégia de internacionalização do produto, as campanhas publicitárias da marca passam também a ser direcionadas para o público estrangeiro, reforçando elementos já convencionais da cultura brasileira e incluindo novos. O Brasil, para Havaianas, continua sendo um país marcado pelo samba, futebol, praias e belos corpos femininos (figura 10).

A ideia de que a marca porta o Brasil começa a ganhar cada vez mais força simbólica e literal. Não parece mais necessário informar os locais de uso do produto ou suas características funcionais. Os textos, imagens e discursos da marca, a partir dos anos 2000, fixam-se em um repertório brasileiresco. Surge, então, a noção de que calçar as sandálias Havaianas, não importa onde se

Figura 9

Sandálias Havaianas utilizam a bandeira do Brasil (1998). Na legenda lê-se "Trazemos o Brasil no peito. Peito do pé, mas peito" e "Os americanos colocaram a bandeira deles na lua. Grande coisa".

Fonte: Edição especial do jornal Memória da Propaganda, ano 4, edição 11 , nov./dez. 2004.

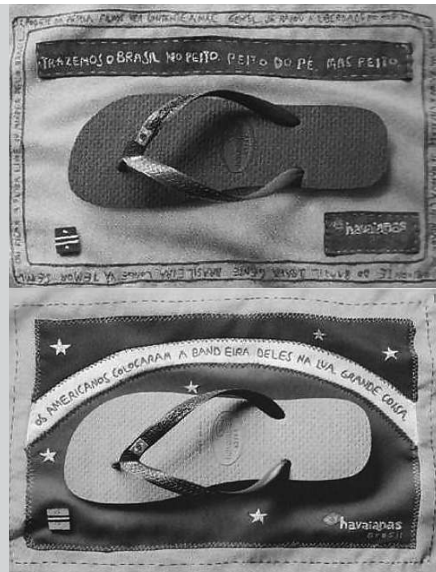

Figura 10

Sandálias Havaianas são divulgadas na Europa (2009 e 2004). Na legenda lê-se: "The Equator, now closer to Europe. Havaianas" ("O Equador agora próximo da Europa. Havaianas") e "Agora eu entendo o Cousteau".

Fonte: Anúncio veiculado em diversos países europeus, obtido junto ao sítio oficial da marca na web: www.havaianas.com.

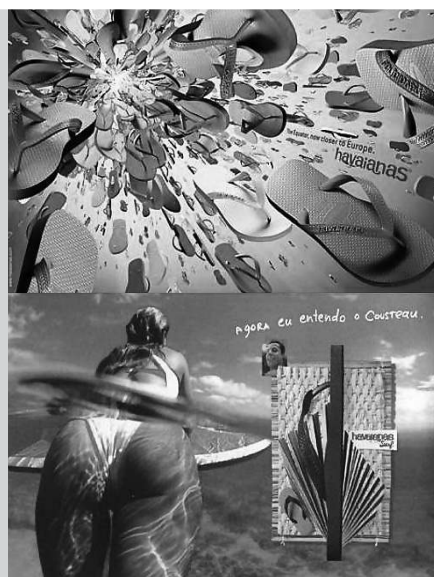


esteja, é pisar, um pouco, no Brasil mesmo, como se o objeto contivesse, em sua essência material, os elementos da brasilidade.

Mas por que certos elementos - e não outros - são entendidos de maneira amplamente compartilhada enquanto legitimamente brasileiros? Por quê o futebol, o Carnaval, o corpo da mulher brasileira? Com efeito, as convenções capazes de identificar o Brasil e os brasileiros foram, outrora, invenções. Se existe uma dialética permanente nos processos de convenção e invenção, então, somente a partir de invenções eficazes podemos - reforçando-as e reinventado-as - identificá-las. Isso ocorre porque a percepção e a compreensão dos outros só pode proceder mediante uma espécie de analogia; assim, nosso conhecimento é produzido por meio de uma extensão do familiar, de modo que cada invenção passa a ser, também, um estilo de entendimento. Wagner escreve:

“Quando um antropólogo estuda outra cultura, ele a 'inventa' generalizando suas impressões, experiências e outras evidências como se estas fossem produzidas por alguma 'coisa' externa. Desse modo, sua invenção é uma objetificação, ou reificação, daquela 'coisa'. Mas para que a cultura que ele inventa faça sentido para seus colegas antropólogos, bem como para outros compatriotas, é necessário que haja um controle adicional sobre sua invenção. Ela precisa ser plausível e plena de sentido nos termos de sua própria imagem de "cultura'" (2010 [1975]: 61, aspas no original).

É por essa razão que Havaianas, ao manipular elementos tidos como convencionais e facilmente identificáveis para os brasileiros e, sobretudo, para não brasileiros, cria e recria esses elementos como verdadeiramente pertencentes à cultura brasileira, tornando-a real, verossímil, plausível.

Entretanto, os próprios profissionais que trabalharam no desenvolvimento e na divulgação recente da marca - a partir da década de 1990 - se mostram surpresos com a aceitação e a repercussão do produto. De acordo com o publicitário Marcelo Serpa, "Havaianas atingiu o nível máximo que uma marca pode alcançar. Além de ser item de moda se tornou em um cult, um clássico. É uma simples sandália de borracha. Não é algo caríssimo que as pessoas não possam adquirir, mas é uma marca de prestígio no mercado internacional, que carrega o DNA brasileiro". ${ }^{11}$

Afirmar, entre outras coisas, que uma marca é capaz de "carregar o DNA brasileiro" não se configura, apenas, como uma forte expressão de linguagem. Quando os administradores, publicitários e profissionais de marketing falam

11 Marcelo Serpa, diretor da agência de propaganda Almap/BBDO, principal responsável pelas campanhas publicitárias da marca Havaianas a partir da década de 1990, em depoimento cedido para produção do DVD Memória da Propaganda, 2001, volume 1, edição especial Sandálias Havaianas. 
sobre suas criações, buscam expressar aquilo que almejam, mas também acabam por refletir aquilo que pensam e como entendem o produto de suas atividades:

"Entre outras coisas a mídia impressa é, no mínimo, brilhante, eu posso falar isso porque não sou eu quem desenha, eu faço parte da equipe que aprova, e eu acho brilhante, a gente conseguiu transformar um simples pedaço de borracha numa coisa aspiracional, numa coisa desejável. Eu brinco que embora seja uma coisa que se coloca nos pés, muitos dos anúncios de Havaianas têm um apelo quase gustativo, dá vontade de comer, dá vontade de pegar, dá vontade de apertar. Quando a pessoa vira a página de uma revista e vê um anúncio de Havaianas, aquilo salta aos olhos, dá vontade de experimentar". ${ }^{12}$

Rui Porto é, com efeito, um dos grandes entusiastas da marca Havaianas, na maior parte das entrevistas que fornece utiliza a voz "oficial" para falar sobre a marca, um discurso orgulhoso sobre o sucesso e as belezas daquilo que ajudou a construir. $^{13}$

A marca Havaianas - o que inclui seu produto, suas imagens e o imaginário de Brasil que engendra - torna-se o "outro" da relação, por meio do estabelecimento de conexões mediadas e ambíguas. Sua "faculdade mimética", como ensinou Taussig (1993), cria uma segunda natureza, aquela que remete diretamente à "natureza do povo brasileiro" dotado de especificidades que permitem identificá-lo. Quando a marca Havaianas idealiza modelos de comportamento e explora as diferenças, esforça-se, então, para tornar-se "outro", apropriando-se da força e da pujança daquilo que "imita".

Coombe (1996: 202) argumenta que as marcas funcionam, notadamente, como um "outro incorporado". O esforço de sua circulação e as complexas camadas de suas dimensões de entendimento remetem diretamente à alteridade, pois, se a imitação ou a simpatia são os princípios da mimesis, a marca é a cópia palpável, a conexão tátil entre aquilo que é incorporado e imaginado.

A abordagem de Gell (1998: 104) também atenta para o fato de que o signo é parte do objeto. Portanto, uma imagem não carrega apenas uma representação do objeto, mas o carrega parcialmente; assim, “a imagem contém o objeto e aquilo que ele significa”. As imagens das sandálias Havaianas não são apenas

12 Rui Porto, diretor de comunicação e mídia da marca Havaianas, em depoimento cedido para a produção do DVD Memória da Propaganda, 2001, volume 1, edição especial Sandálias Havaianas.

13 A relação dos profissionais de marketing e comunicação com suas "criações" é bastante peculiar: ao mesmo tempo em que se sentem responsáveis pelos efeitos e consequências das estratégias que criam, sentem-se também surpresos com seus resultados, os quais, muitas vezes, são atribuídos aos próprios objetos. Sobre a realização de etnografia em ambientes empresariais e contextos de produção contemporâneos do marketing e da publicidade ver Ribeiro (201 l) e Miller (2006). 
portadoras do calçado de borracha que apresentam, mas portam, sobretudo, o Brasil mesmo, o povo brasileiro e, ainda, aquilo que entendemos por cultura brasileira.

Devido ao fato de as sandálias Havaianas serem vendidas em mais de 60 países - desde os anos 2000 -, a fragmentação e circulação de suas imagens adquiriu uma proporção demasiadamente vasta. Assim, são produzidas campanhas e anúncios publicitários diferenciados para cada país onde a marca é comercializada. Muitas vezes, as palavras e frases nos anúncios para divulgação da marca em outros países permanecem em língua portuguesa, reforçando os traços de identidade da marca, não apenas com seu país de origem, mas com o idioma que o objeto "fala".

Débora Leitão (2007: 207) demonstra como as marcas brasileiras, incluindo a marca Havaianas, utilizam-se de elementos como o exotismo para constituir-se enquanto produtos interessantes e alternativos em países europeus. Sobre esse fenômeno, Leitão explica:

"O uso de palavras brasileiras em textos, anúncios ou falas francesas a respeito de nossa moda é um tanto comum. Tratando inicialmente de suas aparições na imprensa francesa, por vezes, tal recurso linguístico é empregado sem que o termo venha acompanhado de qualquer tradução ou explicação, sob forma de expressões como 'tudo bem', 'bumbum', 'entre na dança'. Talvez ali aplicadas muito mais por sua sonoridade, dizem respeito ao reforço do aspecto curioso e desconhecido do produto exótico" (Leitão 2007: 217).

Observamos, através da história de vida da marca Havaianas, que esta não esteve durante toda sua trajetória ligada aos elementos representativos da brasilidade. As alterações e mudanças no curso de sua história e no decorrer da circulação de suas imagens fizeram com que a marca expandisse seus universos de significação, passando a agir de diferentes maneiras. Através da circulação fragmentária da marca Havaianas, percebemos um complexo processo de agenciamento. Havaianas, em sua trajetória social, reforça hábitos, práticas e modos de identificação que moldam e constroem um povo, uma nação e um país, capaz de reconhecer-se no samba, na comida, nos corpos e nos gestos.

Seus modos de conceitualização exotizam o familiar e ressimbolizam elementos da brasilidade convencional - é por essa razão que eles aparecem tão frequentemente reduzidos ou literalizados. Havaianas faz, assim, uma autêntica metaforização dos diversos fenômenos da vida e do pensamento, em termos de nossa cultura e passando, necessariamente, pela invenção criativa do ato de representar um povo ou nação. Discutirei, a seguir, como este processo inventivo tornou-se possível através da hábil articulação entre convenção e invenção realizada pela marca. 


\section{A INVENÇÃO DA BRASILIDADE}

A evidência de uma cultura brasileira pode aparecer consubstancializada em elementos diversos e até mesmo contraditórios. Entre aqueles demasiado conhecidos pelo senso comum figuram o futebol, a caipirinha, a feijoada, o Carnaval, os belos corpos femininos, a alegria e a descontração do povo do Brasil; mas, o que acontece quando a cultura brasileira toma a forma de sandálias de borracha?

Dentre as diferentes formas de existência da marca Havaianas, aquelas que dizem respeito às associações - tanto dos padrões estéticos quanto de identidade - da marca com os elementos de identificação da cultura de seu país de origem apareceram, como vimos, em diferentes períodos e contextos. Essa associação vem conformando-se como um caso extremamente potente de vinculação aos aspectos expressivos de reconhecimento da cultura brasileira em decorrência de uma larga estratégia de construção desse objeto enquanto um elemento autêntico de pertencimento à referida cultura.

Apesar do caráter constitutivo da noção de cultura brasileira engendrada pela marca Havaianas e de seu uso para fins comerciais e mercadológicos, parece, todavia, que seus sentidos são capazes de produzir outras consequências além da venda de sandálias de borracha. Isso significa, sobretudo, que os elementos mobilizados pela marca Havaianas, os quais contribuem, moldam e formulam determinada noção de cultura brasileira, revelam o verdadeiro caráter da crença social nessa noção, incutida não apenas nos profissionais de marketing, empresários, publicitários e gestores da marca em geral, mas também nos consumidores e pessoas que adquirem o produto.

O sucesso deste objeto no Brasil e no exterior é a comprovação da eficácia da noção de cultura na qual a marca se insere. Assim, não se trata de uma versão falsa, caricatural ou fantasiosa sobre a cultura brasileira; trata-se, antes, de uma invenção eficaz dessa cultura, como são, aliás, todas as invenções. O que a marca Havaianas fez foi expandir metaforicamente os elementos retirados de sua experiência com aquilo que identificou como cultura brasileira, ou seja, ao experimentar e vivenciar dada cultura ela é produzida e expandida, comunicada nos termos passíveis de compreensão por seu universo.

Wagner (2010 [1975]: 19) nos indica um caminho que permite entender os dois modos principais de simbolização a partir dos quais a cultura opera. Um modo está articulado à convenção e o outro, por sua vez, à invenção. A simbolização convencional estabelece relações entre elementos no interior de um campo discursivo, agregando os signos dentro de um determinado padrão; assim, opera uma rotulação ou codificação "dos detalhes do mundo" em que são ordenados. Esta forma de simbolização torna convencionais as associações e, portanto, permite aos símbolos serem compartilhados e, assim, servirem de base para a comunicação entre os agentes. Em outras palavras, 
toda sociedade precisa inventar convenções porque são elas que dão consistência ao mundo.

A convencionalização, entretanto, não impede a invenção - pelo contrário, incita-a. Temos aqui, portanto, uma ideia de fluxo contínuo de invenções. Afinal, de acordo com Wagner, "a necessidade da invenção é dada pela convenção cultural e a necessidade da convenção cultural é dada pela invenção. Inventamos para sustentar e restaurar nossa orientação convencional; aderimos a essa orientação para efetivar o poder e os ganhos que a invenção nos traz" (2010 [1975]: 96). Assim, a ideia de controle que a convenção pode carregar é apenas uma espécie de segurança necessária, uma vez que as convenções são o suporte para as invenções.

Ora, se as convenções são necessárias para orientar as invenções, logo, as convenções que permitem identificar a existência de uma cultura brasileira orientam as invenções dessa mesma cultura, tal como aparece no modo de operação da marca Havaianas. Através de elementos convencionalizados e reconhecidos socialmente como pertencentes e capazes de identificar o Brasil e os brasileiros, a marca Havaianas pôde inventar, à sua moda, o Brasil e os brasileiros. Deste modo, podemos encarar a invenção cultural como um sucessivo processo de metaforizações, de associações e extensões de elementos simbólicos cujo sentido pode ser mais ou menos literal, dependendo do contexto de controle. Nessa dinâmica, a cultura não só objetifica a realidade por meio de convenções, como também a inventa a partir do simbolizar convencional.

As invenções nas quais o mundo se realiza só se tornam possíveis mediante o fenômeno do controle e o mascaramento que o acompanha; assim, as distinções convencionais nas quais o controle se baseia só podem ser estendidas ao serem recriadas no curso da invenção. Isto é, quando a marca Havaianas se propõe a conhecer e, sobretudo, a comunicar a cultura brasileira, ela passa, então, a inventá-la.

Para além dos interesses comerciais, mercadológicos e corporativos da São Paulo Alpargatas em promover a vinculação de seu produto à cultura de seu país de origem como forma estratégica de promover sua diferenciação no mercado, interessa, antes, observar as motivações dos objetos e das imagens em nível radical. Seguindo Wagner (2010 [1975]), é assim possível pensar os diferentes agenciamentos da marca, ao longo dos últimos quase 50 anos, a partir de um recorte temático capaz de atravessar tempos, sentidos e tecnologias na busca de uma constituição sólida deste objeto como pertencente à cultura brasileira.

O ponto crucial, entretanto, está no fato de essa constituição não ser mera estratégia de pertencimento, isto é, não se trata de aproximar direta e circunstanciadamente a marca Havaianas aos aspectos socialmente reconhecidos como aqueles dotados de brasilidade. Trata-se, antes, de um complexo exemplo de agência exercida por entidades não humanas - como são os objetos, imagens, 
mercadorias e marcas -, ou seja, na observação e análise da trajetória de vida da marca Havaianas no Brasil encontramos um processo, ao mesmo tempo, de replicação, reforço e invenção da cultura brasileira e, devido ao alcance global deste objeto, as suas ações possuem consequências de grande impacto. Deste modo, percebe-se que o efeito desse processo é sempre reflexivo, isto é, aquilo que é simbolizado exerce seu efeito sobre aquilo que simboliza.

O objetivo desta análise é demonstrar que a possibilidade de entendermos o Brasil como cultura só é possível porque esta cultura foi inventada. Diante dessa abordagem podemos, então, refletir sobre uma pequena parte desse complexo processo de invenção cultural. ${ }^{14}$ É por isso que pensar a invenção da cultura brasileira por meio da marca Havaianas se torna um interessante exercício de compreensão do processo de invenção cultural e das expressões de agentes não humanos.

Nessa direção, não há como negar a vivência da marca Havaianas enquanto uma entidade que vem relacionando-se com o país e com todos os seus atributos de identidade de maneira bastante próxima. Ao longo de sua existência, a marca Havaianas não apenas buscou afirmar-se enquanto uma marca brasileira e, portanto, dotada de brasilidade, mas também afirmou-se como um agente atribuidor de brasilidade, ou seja, a marca Havaianas, simultaneamente, contém e transmite a cultura brasileira.

Se, de acordo com Wagner (2010 [1975]: 30), "um antropólogo inventa a cultura que ele acredita estar estudando", a marca Havaianas, por sua vez, também parece inventar a cultura à qual busca pertencer, pois é no processo de "conhecimento" da cultura que esta se torna "visível" e, por conseguinte, plausível, identificável, reconhecível. Entre todas as consequências do processo que "torna visível" uma cultura através de sua invenção, encontramos aquelas ligadas ao fato de essas ações serem efetivadas por uma entidade não humana, neste caso os chinelos de borracha.

Logo, a marca Havaianas, uma aspirante a nativa brasileira, só conseguiria ingressar num mundo criado por ela mesma ou, para falar como Wagner (2010 [1975]: 37), "como faria um esquizofrênico ou aquele apócrifo pintor chinês que, perseguido por credores, pintou um ganso na parede, montou nele e fugiu voando!" A efetivação da marca Havaianas como ícone dotado de brasilidade é delineada por meio de uma concretização inventiva dessa entidade como tal. O mundo da marca Havaianas é, com efeito, o mundo da cultura brasileira, um mundo inventado por ela, para que nele possa existir.

14 Cabe lembrar, contudo, que o monopólio de invenções eficazes sobre as culturas ou, neste caso, sobre a brasilidade, não pertence ao Estado, tampouco às ciências sociais. Assim, observamos, incessantemente, elementos quotidianos como a mídia, a publicidade ou os meios de comunicação, de forma geral, a participar desse processo dialético que articula convenção e invenção. 


\section{CONSIDERAÇÕES FINAIS}

Este artigo apresentou uma análise centrada na vida social de um objeto particular. A trajetória de vida dos chinelos de borracha alertou para a capacidade de ação de objetos e marcas no universo do consumo de mercadorias e no âmbito das práticas industriais.

Observar a marca de sandálias Havaianas mostrou-se um exercício profícuo para compreendermos a circulação de objetos contemporâneos e seus efeitos sociais. Suas imagens publicitárias e o trabalho de campo em ambientes empresariais serviram como importantes guias de acesso que permitiram a reconstrução histórica e visual desta marca. Tal trajetória deixou ver os diversos elementos, ideias e imaginários culturais compartilhados, tanto por pessoas como por coisas.

Um dos argumentos principais desse trabalho foi mostrar quão complexos podem ser os efeitos sociais da existência de entidades não humanas; neste caso, a marca Havaianas pôde inventar os brasileiros e os fazer reconhecíveis através de características objetificadas em suas imagens publicitárias, em seu chinelo de borracha, em sua marca. Em hipótese radical, as sandálias Havaianas não compartilham apenas nosso mundo, elas compartilham também nossa humanidade, quando se tornam actantes no processo de fabricação da sociabilidade.

A marca Havaianas atrai os expectadores de diferentes maneiras, operando como uma assinatura de autenticidade, não apenas do objeto, mas de toda a ideia construída em torno dele. A autenticidade que evoca é, com efeito, uma autenticidade brasileira. Ao analisar a trajetória de vida da marca Havaianas percebemos que os bens materiais não são bens quaisquer; ao contrário, são entidades bastante específicas e singulares, dotadas de características que as fazem únicas em seus modos de significar. O conjunto de imagens analisadas e as entrevistas com os profissionais que trabalharam no processo de constituição dessa marca no Brasil auxiliaram a levantar as características singulares desta marca, reconhecida no universo de bens com a mesma veemência com que pessoas o são.

Este texto atentou para a necessidade latente de desvelar a maneira pela qual cada marca, no universo do consumo de bens, pode ser entendida como dotada de uma historicidade única. As marcas podem ser apreendidas enquanto "outros" sociais dotados de agência e sensibilidade. Isso significa, especialmente, que as marcas agem de modo muito particular. Como o trabalho demonstrou, no caso da marca Havaianas, ela faz, com muita especificidade, o que nenhuma outra faz de maneira idêntica. Assim, a marca Havaianas faz-se expressiva e eficaz em seu ato de invenção da brasilidade, tornando-se, notadamente, um elemento reconhecível como pertencente ao Brasil, fazendo-se um "outro" incorporado e metaforizado em suas características de identificação. 
Ao percorrer sua trajetória buscou-se compreender como um objeto cria a si mesmo e, ao criar-se, inventa o mundo em que vive. Ao longo deste trabalho, refletimos sobre a noção de cultura - terreno pleno da antropologia e como esta pode ser pensada por outros universos de significação. Entre estes universos estão aqueles demasiadamente conhecidos por nós, como são o dos movimentos sociais, das populações indígenas e das comunidades tradicionais, inegáveis possuidores de cultura; entretanto, bens materiais também a reivindicam para si, e a eles temos fechado nossos olhos. Os objetos e marcas não podem ser considerados meras mercadorias, pois são, antes, entidades complexas que compartilham conosco inúmeras formas de ação; sua capacidade criativa de invenção é tão poderosa e eficiente quanto a nossa própria.

Não faço aqui qualquer apologia ou crítica acerca da invenção de determinado Brasil em detrimento de outro; de todo modo, se a cultura brasileira não existe, então parece necessário inventá-la, ou, se ela de fato existe, isso torna ainda mais urgente sua invenção - afinal, a invenção é a forma da nossa experiência, a possibilidade máxima do nosso entendimento. Em outras palavras, se reconhecemos a criatividade do antropólogo na construção de sua compreensão sobre outras culturas, certamente não poderemos negar a essas culturas e aos seus membros o mesmo tipo de criatividade.

Se assumimos, como fez Wagner (2010 [1975]: 76), que no limite todo ser humano é um antropólogo, segue-se que todas as pessoas necessitam de um conjunto de convenções compartilhadas. Assim, a marca Havaianas não fez nada além daquilo a que nós, antropólogos, estamos habituados: inventou um Brasil e um brasileiro e os fez existir como cultura.

\section{BIBLIOGRAFIA}

ADAM, Jean-Michel, e Marc BONHOMME, 2005, Analyses du discours publicitaire. Toulouse, Editions Universitaires du Sud.

APPADURAI, Arjun (org.), 1986, The Social Life of Things: Commodity in Cultural Perspective.

Cambridge, Cambridge University Press.

BARTHES, Roland, 1957, Mythologies. Paris, Editions du Seuil.

BARTHES, Roland, 1967, Système de la mode. Paris, Editions du Seuil.

BARTHES, Roland, 1970, L'empire des signes. Paris, Skira.

BARTHES, Roland, 1990, O Óbvio e o Obtuso: Ensaios Críticos III. Rio de Janeiro, Nova Fronteira.

BAUDRILlARD, Jean, 1968, O Sistema dos Objetos. São Paulo, Editora Perspectiva.

BAUDrillard, Jean, 1970, A Sociedade de Consumo. Lisboa, Edições 70. 
BAUDRILLARD, Jean, 2000 [1982], "Significação da publicidade”, em Luis Costa Lima (org.), Teoria da Cultura de Massa. Rio de Janeiro, Editora Paz e Terra, 273-280.

BOURDIEU, Pierre, 2007 [1979], A Distinção: Crítica Social do Julgamento. São Paulo, Edusp; Porto Alegre, Zouk.

CAMPBELL, Colin, 2006, "Eu compro, logo sei que existo: as bases metafísicas do consumo moderno”, em Lívia Barbosa (org.), Cultura, Consumo e Identidade. Rio de Janeiro, Editora FGV, 47-64.

CATHElat, Bernard, 2001, Publicité et société. Paris, Payot.

CHARAUDEAU, Patrick, 1994, "Le discours publicitaire: genre discoursif", Mscope, 8: 34-44.

COOMBE, Rosemary, 1996, "Embodied trademarks: mimesis and alterity on American commercial frontiers”, Cultural Anthropology, 11 (2): 202-224.

DEBORD, Guy, 2000, A Sociedade do Espetáculo. Rio de Janeiro, Editora Contraponto.

DOUGLAS, Mary, e Baron ISHerWOOD, 2006 [1979], O Mundo dos Bens: Para Uma Antropologia do Consumo. Rio de Janeiro, Editora UFRJ.

FLOCH, Jean-Marie, 2002, Sémiotique, marketing et communication : Sous les signes, les stratégies. Paris, Presses Universitaires de France.

GELL, Alfred, 1998, Art and Agency: An Anthropological Theory. Oxford, Oxford University Press.

GREVEN, Hubert, 1982, La langue des slogans publicitaires. Paris, Presses Universitaires de France.

GRUNIG, Blanche-Noëlle, 1998, Les mots de la publicité: L'architecture du slogan, Paris, CNRS.

HAINEAULT, Doris-Louise, e Jean-Yves ROY, 1984, L'inconscient qu'on affiche: Essai psychanalytique sur la fascination publicitaire. Paris, Aubier.

JOLY, Martine, 1994, Introdução à Análise de Imagens. Lisboa, Edições 70.

KEHL, Maria Rita, 1998, Deslocamentos do Feminino: A Mulher Freudiana na Passagem para a Modernidade. Rio de Janeiro, Imago Editora.

KOPYTOFF, Igor, 1986, “The cultural biography of things: commoditization as process”, em Arjun Appadurai, The Social Life of Things: Commodity in Cultural Perspective. Cambridge, Cambridge University Press, 64-91.

LEITÃO, Débora Krischke, 2007, “Nós, os outros: a construção do exótico e consumo de moda brasileira na França”, Horizontes Antropológicos, 29: 203-230.

MALEFYT, Timothy Dewaal, e Brian MOERAN (orgs.), 2003, Advertising Cultures. Oxford, Berg.

MILLER, Daniel, 2003, "Advertising, production and consumption as cultural economy", em Timothy Dewaal Malefyt e Brian Moeran (orgs.), Advertising Cultures. Oxford, Berg, 75-89.

MILLER, Daniel, 2006, The Cell Phone: An Anthropology of Communication. Londres, Berg.

MINOT, Françoise, 2001, Quand l'image se fait publicitaire: Approche théorique, méthodologique et pratique. Paris, Editions L'Harmattan.

PACKARD, Vance, 1958, La persuasion clandestine. Paris, Calmann-Lévy.

PEREIRA, Rosane da Conceição, 2006, Discurso e Publicidade: Dos Processos de Identificação e Alteridade pela Propaganda Brasileira. Rio de Janeiro, Universidade Federal Fluminense, tese de doutorado.

RIBEIro, Magda dos Santos, 2011, Das Coisas e Suas Invenções: Antropologia no Mundo das Marcas. São Paulo, Universidade de São Paulo, dissertação de mestrado.

SAHLINS, Marshall, 2003 [1976], Cultura e Razão Prática. Rio de Janeiro, Jorge Zahar Editor. 
SOUZA, Marcela Stockler Coelho de, 2012, "A pintura esquecida e o desenho roubado: contrato, troca e criatividade entre os Kisêdjê", Revista de Antropologia, 55 (1): 209-253. TAUSSIG, Michael, 1993, Mimesis and Alterity: A Particular History of the Sense. Londres, Routledge.

WAGNer, Roy, 2010 [1975], A Invenção da Cultura. São Paulo, Cosac Naify. 